MIGRAÇÃO DE RESÍDUO DE PENTACLOROFENOL DE EMBALAGEM SECUNDÁRIA DE GELATINA COMESTÍVEL

\title{
MIGRATION OF PENTACHLOROPHENOL RESIDUE FROM SPIKED SECONDARY PAPERBOARD PACKAGING TO EDIBLE GELATIN
}

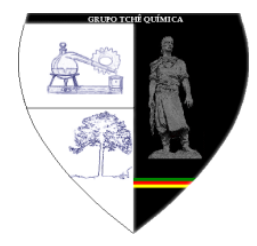

FIORI ${ }^{1}$, Raquel*; BRANDELLI ${ }^{1}$,Adriano ; Noreña ${ }^{1}$,Caciano P.Z.; PIZZOLATO ${ }^{3}$, Tânia M.

${ }^{1}$ Programa de Pós-Graduação em Ciência e Tecnologia de Alimentos, Instituto de Ciência e Tecnologia de Alimentos, Universidade Federal do Rio Grande do Sul, 91501-970 Porto Alegre, Brasil

${ }^{2}$ Instituto de Química, Universidade Federal do Rio Grande do Sul, 91501-970 Porto Alegre, Brasil

**Corresponding author: e-mail : rfsouza@hotmail.com - fone:(51)9682.5436

Received 09 May 2016; received in revised form 12 July 2016; accepted 15 July 2016

\section{RESUMO}

A exposição do consumidor a substâncias nocivas com origem nas embalagens que entram em contato com os alimentos pode ocorrer como resultado da migração dessas por via intencional ou não, incorporados na alimentação ao longo da cadeia. O papel e o cartão são usados em contato com alimentos secos, e por isso vistos pelo consumidor como "saudáveis". Tendo em vista que a gelatina é muito consumida por crianças e atletas e que a madeira da qual são feitas as embalagens sofrem procedimentos químicos com o inseticida pentaclorofenol (PCP) para sua conservação, estudou-se a transferência e a incorporação do PCP para a embalagem secundária de gelatina comestível, provando uma ineficácia da barreira com o uso do polipropileno (PP) como embalagem primária. Os resultados indicaram a migração em temperatura elevada $\left(60^{\circ} \mathrm{C}\right)$ em um curto período de tempo $(48 \mathrm{~h})$ quando a embalagem secundária foi fortificada com PCP derivatizado na concentração de $0,01 \mathrm{mg} \mathrm{L}^{-1}$ e colocada em contato com a gelatina seca acondicionada em sachês originais de polipropileno. Outros trabalhos também apontam a migração de poluentes químicos incluindo os clorofenóis e enfatizam a importância desse tipo de pesquisa frente ao que representa como risco de contaminação subaguda.

Palavras-chave: PCP; migração; papel cartão

\begin{abstract}
The consumer exposure to the new harmful substances with origin in packaging which have contact with the food can occur as a result of their intentional migration or not incorporated in the food during the food chain. The paper and the cardboard are used in contact with dry food and that is because of this it is seen by the consumer as "healthy". Considering that the gelatin is too consumed by children and athletes and the wood from which the packaging are made suffer chemical procedures with the insecticide pentachlorophenol (PCP) for their preservation, studied the transference and the incorporation of PCP in the secondary packaging of the edible gelatin proving effectiveness from the barrier with polypropylene (PP) use as a primary packaging. The results indicate the migration with high temperature $\left(60^{\circ} \mathrm{C}\right)$ in a short period of time $(48 \mathrm{~h})$ when the secondary packaging was fortified with derivatised PCP into $0,01 \mathrm{mg} \mathrm{L}^{-1}$ concentration and put in contact with dry gelatin secured in polypropylene sachet. Others papers also point out the migration of chemical pollutants including chlorophenol and emphasize the importance of this research represent like a risk of sub-acute contamination.
\end{abstract}

Keywords: PCP; migration; cartonboard

PERIÓDICO TCHÊ QUÍMICA • www.periodico.tchequimica.com • Vol. 13 N. 26.

• ISSN 1806-0374 (impresso) • ISSN 1806-9827 (CD-ROM) • ISSN 2179-0302 (meio eletrônico)

(C) 2016. Porto Alegre, RS. Brasil 


\section{INTRODUCION}

The paper and cellulose sector in Brazil contributes strongly for the economic and social development, producing 10.1 million tons of paper per year. In the global ranking, Brazil is the $7^{\text {th }}$ world producer of cellulose and reached the $11^{\text {th }}$ place in the production of paper in 2007 (Brazilian Pulp and Paper Association, 2008).

Paper and paperboard are composites of pulp of vegetal sources as the wood of planted forests (Pinus and Eucalyptus) normally used as food packaging materials frequently in forms adapted to direct contact with dry foodstuff. These materials are frequent seen by the consumer as healthful, but diverse additives are incorporated during the production such as agents of resistance, whitening, preservatives, which vary depending on the final purpose. Currently, the negative environmental impact of plastic packaging waste has driven to a gradual push towards the use of biodegradable materials in food packaging. Paper has attractively seen as a material ease of recycling them (Triantafyllou et al., 2002). However, for avoiding attack and development of xylophages microorganisms, some chemicals are using wood preservative and slimicides to a cellulose pulp. Pentachlorophenol (PCP) had been widely used in wood preservation. This chemical is reported to be a potential carcinogen and genotoxic agent causing chromosomal aberration (Demers et al., 2006) and during the burning of PCP-treated materials, polychlorinated dibenzodioxin and dibenzofuran (PCDD/F) may also be formed (Collins et al., 2007). In Brazil, according to the Governmental Decree of the Ministry of Health (ANVISA, 2006), it have excluded the PCP use in June 2006. The only resolution that limits levels $\left(0,10 \mathrm{mg} \mathrm{kg}^{-1}\right)$ in cartonboard packaging materials is the Resolution 130/2002 ANVISA (ANVISA, 2002).

The term migration usually describes a diffusion process, which may be strongly influenced by an interaction of the packaging material with the food, gained a widespread importance in food safety as normal procedure for checking compliance introduced into the legislation. Migration of packaging components can be so small $\left(10,0 \mathrm{ng} \mathrm{g}^{-1}-60,0 \mathrm{mg} \mathrm{kg}^{-1}\right)$ that biological reply in the exposed organisms will not be short-term observed, however after long periods of contaminated food ingestion, subtle toxic manifestations and with difficult detection will be able to occur (Kroes et al., 2000).

The industries that place packaging food or those who manufacture and sell raw materials do not always know the potential migrants identities. Therefore, it is important to analyze the final product as packaging and food to guarantee the quality of products offered for the population. This report verified the migration of PCP from spiked paperboard packaging into dry food as edible gelatin in different temperatures and time, which simulate a typical packaging situation originating indirect contact controlled by a polypropylene film into which the PCP diffused.

\section{MATERIAL E METHODS}

\subsection{Chemicals}

Acetic anhydride, potassium hydroxide, sodium carbonate and sulfuric acid were from Vetec (Rio de Janeiro, Brazil). All reagents were from analytical grade. Acetone, hexane and isopropanol were from pesticide residue grade (Merck, Rio de Janeiro, Brazil). Analytical reference standard of pentachlorophenol was from Dr. Ehrenstorfer $\mathrm{GmbH}$ (Augsburg, Germany).

\subsection{Gelatin samples}

Edible dry gelatin samples $(85 \mathrm{~g})$ in carton box as secondary packaging involving original sachets of polypropylene as primary packaging were used. The area of the carton box and sachets was $234.6 \mathrm{~cm}^{2}$ and $90.25 \mathrm{~cm}^{2}$, respectively. Samples were obtained at a local market.

\subsection{Preparation of PCP for calibration curve}

Standard PCP solutions were prepared in hexane, making appropriate dilutions to give concentrations of 0,$02 ; 0,01 ; 0,1 ; 0,2 ; 0,4 ; 1,0$ and $10,0 \mathrm{mg} \mathrm{L}^{-1}$.

Five milliliters of these solutions were mixed with $20 \mathrm{ml}$ of $0,1 \mathrm{~mol} \mathrm{~L}^{-1} \mathrm{Na}_{2} \mathrm{CO}_{3}$ and $2,0 \mathrm{ml}$ acetic anhydride. Tubes were sealed and shook 30 min on a mechanical shaker, and then allowed to phase separation. Aliquots of $1,0 \mu \mathrm{L}$ from the hexane layer were injected in the GC system.

\subsection{Limits of detection and quantitation for gelatin}

The limits of detection (LOD) and

PERIÓDICO TCHÊ QUÍMICA • www.periodico.tchequimica.com • Vol. 13 N. 26 - ISSN 1806-0374 (impresso) • ISSN 1806-9827 (CD-ROM) • ISSN 2179-0302 (meio eletrônico) 
quantitation (LOQ) were defined as 3 and 10 times the value of noise, respectively. The standard deviation from estimated concentration values of the lowest calibration point was used as a noise measure.

\subsection{Gas chromatography analysis}

A gas chromatography system (Varian Analytical Instruments, USA) equipped with a $\mathrm{Ni}^{63}$ electron capture detector (Varian Star Model $3600 \mathrm{Cx}$ ) and STAR workstation software was used to determine PCP in gelatin and paperboard samples. The separation column was a $12 \mathrm{~m} \mathrm{X}$ $0,20 \mathrm{~mm}$ ID fused silica capillary SPB-5 with a size film of $0,33 \mu \mathrm{m}$ (Supelco). The following GC parameters were kept constant: detector temperature, $300^{\circ} \mathrm{C}$; injector temperature, $250^{\circ} \mathrm{C}$; injection mode, splitless; injection volume, $\quad 1,0$ $\mu \mathrm{L}$.. The column temperature program: initial temperature $100^{\circ} \mathrm{C}$, hold 2 minutes from $100^{\circ} \mathrm{C}$ to

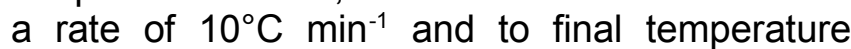
$250^{\circ} \mathrm{C}$, and hold 2 minutes. Carrier gas: ECD grade $\mathrm{H}_{2}$, at a flow rate of $1,0 \mathrm{ml} \mathrm{min} \mathrm{m}^{-1}$. Make up gas: ECD grade $\mathrm{N}_{2}$, at a flow rate of $1,0 \mathrm{ml} \mathrm{min}^{-1}$.

\subsection{Accelerated migration test}

Five milliliters of a standard solution of acetylated PCP $\left(0,01 \mathrm{mg} \mathrm{L}^{-1}\right)$ were sprayed into empty gelatin cardboard packaging (area $\left.=234,6 \mathrm{~cm}^{2}\right)$, which was allowed to dry. The dry gelatin samples involved in the polypropylene original closed sachets were replaced into spiked packaging, closed and stored at 25,40 or $60^{\circ} \mathrm{C}$ for $3,6,24$ and $48 \mathrm{~h}$. After each exposure, it was proceeded the extraction according to the analytical method adopted.

\subsection{Analytical procedure}

The method applied for PCP in gelatin (AOAC, 1985) consists on gelatin acid hydrolysis with $\mathrm{H}_{2} \mathrm{SO}_{4}$ solution, originating an homogeneous hydrolysate to ease the PCP extraction with hexane. Partition with $\mathrm{KOH}$ solution executes the function of cleaning to separate the acid and PCP compounds.

Dry gelatin samples were removed from secondary cardboard packaging and opened the sachets. Dry gelatin samples $(2,0 \mathrm{~g})$ were hydrolyzed with $10,0 \mathrm{ml}$ of $6 \mathrm{~mol} \mathrm{~L}^{-1} \mathrm{H}_{2} \mathrm{SO}_{4}$ in tightly cap tubes heated for 60 minutes at $100^{\circ} \mathrm{C}$ in water bath. During this hydrolysis, tubes were periodically removed to mix samples by carefully hand shaking. After 1 hour, the samples were allowed to cool and 10,0 ml hexane-isopropanol $(4: 1, \mathrm{v} / \mathrm{v})$ were added and the mixture was shook for 2 minutes. The mixture was centrifuged for 2 minutes at $1800 \times g$ and the upper hexane layer was transferred to some clean tubes. The extraction was repeated twice and all the hexane extracts were combined. In these tubes, $5,0 \mathrm{ml}$ of $1 \mathrm{~mol} \mathrm{~L}^{-1} \mathrm{KOH}$ were added; tubes were sealed and shook for 2 minutes, centrifuged and the upper layer was removed and discarded. Hexane $(10,0 \mathrm{ml})$ was added to the extract, and after mixing and centrifuging the hexane phase was removed and discarded. Ten milliliters of the final extracts were transferred to a volumetric flask. A blank reagent was prepared in parallel using this same procedure.

\section{RESULTS AND DISCUSSION:}

Dry gelatin samples were exposed to secondary packaging artificially contaminated with PCP and investigated for this chlorophenol presence. Among the time and temperature tested conditions, PCP was detected in the samples exposed at $40^{\circ} \mathrm{C}$ for $48 \mathrm{~h}$ and at $60^{\circ} \mathrm{C}$ for $6,24,48 \mathrm{~h}$ (Table 1 ).

Table 1. Migration of PCP from cardboard packaging to gelatin*

\begin{tabular}{lcccc}
\hline & \multicolumn{4}{c}{ Exposition } \\
\cline { 2 - 5 } Temperature time \\
\cline { 2 - 5 } & $3 \mathrm{~h}$ & $6 \mathrm{~h}$ & $24 \mathrm{~h}$ & $48 \mathrm{~h}$ \\
\hline $25^{\circ} \mathrm{C}$ & $<0.02$ & $<0.02$ & $<0.0$ & $<0.0$ \\
& & & 2 & 2 \\
$40^{\circ} \mathrm{C}$ & $<0.02$ & $<0.02$ & $<0.0$ & 0.02 \\
& & & 2 & \\
$60^{\circ} \mathrm{C}$ & $<0.02$ & 0.02 & 0.02 & 0.06 \\
\hline${ }^{*}$ Values for PCP are expressed as $\mathrm{mg} \mathrm{kg}^{-1} ;$ & & $<0.02$ \\
correspond to values below LOD. & & &
\end{tabular}

Gas chromatography equipped with electron capture detector (GC-ECD) was used to identify the contaminant PCP into dry gelatin samples. Typical GC-ECD chromatograms are shown in Figure 1.

The clear peaks were obtained at the same retention time as those of standards in hexane. The quality criteria applied was: Time of the sample retention should be the same as the pattern in the rate of 9,63 minutes; a signal-to- 
noise ratio of 3 for the detection limit (LOD); LOD was calculated from calibration standards. The calibration curve linearity obtained the correlation coefficient $r^{2}=0,998$ and according Rieder et al. (2000), it is considered the strongest correlation with minor dispersion on set of points located in the curve. LOD was in the range of $0,02 \mathrm{mg} \mathrm{kg}^{-1}$ and repeatability was calculated using the Relative Standard Deviation (RSD) obtained range $1 \%$.

The PCP migration of the secondary cardboard packaging to the gelatin matrix after incubation) for the temperatures of $40^{\circ} \mathrm{C}$ and $60^{\circ} \mathrm{C}$ they are presented in Figure $2 \mathrm{~A}$. At $40^{\circ} \mathrm{C}$ migration occurred only in $48 \mathrm{~h}$, but at $60^{\circ} \mathrm{C} \mathrm{PCP}$ migration was observed in $6 \mathrm{~h}$. It was observed how fast the migration from paper box packaging occurs to dry gelatin in elevated temperatures and short periods, through polypropylene film that is generally used as barrier to migration. The PCP migration from secondary paperboard packaging to gelatin showed a good fit to the exponential model, with $r^{2}$ value of 0,979 (Figure 2B).

PCP showed ability to migrate from a secondary packaging to a dry food matrix, in this case, edible gelatin. Migration kinetics often depends on the temperature, nature and paper properties (like the size), and nature of the contaminant (chemical structure and physical properties). PCP has relatively high molecular mass $\quad\left(266 \mathrm{~g} \mathrm{~mol}^{-1}\right)$ getting itself relatively low migration rates (Choi et al., 2002). Papers and porous structures are relatively open and they are allowing that the contaminants are transferred to the fatty and dry food in short period of exposure.)

Efficient and fast migration of chemical
pollutants, including chorophenols from paperboard to selected dry food has been reported (Anderson \& Castle, 2003; Triantafyllou et al., 2006). PCP has received special attention in order to measure the levels that can be transferred to food for direct contact (Triantafyllou et al., 2006; Summerfield \& Cooper, 2001; Song et al., 2003; Diserens, 2001; Ozaki et al., 2004).

However, primary polypropylene packaging was not capable to avoid PCP migration. Some researchers have investigated the effectiveness of polypropylene and polyethylene films as barriers to contaminant migration to water. They found that such films were not effective as barriers to some chemicals, such as anthracene, benzophenone and PCP (Choi et al., 2002; Song et al., 2003).

\section{CONCLUSION}

It is alarming the fact that the food products as being the packing contaminated in the origin, can become tainted by even low concentrations of undesirable compounds such as PCP. This situation is real if the products are stored under inadequate conditions. Particularly, gelatin is greatly consumed by children and athletes. Gelatin is normally consumed by children in the diet school at least once a week (Teppner, 2004) and for athletes it is an indicated a dessert before a competition (Di Pasquale, 1997). However, can represent a risk of subacute contamination.

Therefore, similar studies should be developed with other contaminants simulating the real situation in the properly sample and not only determined in solvent simulations. These experimental data are relevant for being monitorize the packaging material of food to the toxic compounds research which could effectively be transferred to the alimentary products. Such results can help the vigilance agencies of health to oversee them whether they are following the legislation.

\section{ACKNOWLEDGEMENTS}

The authors thank the staff of the Secretary of Health - Central Public Health Laboratory of Rio Grande of Sul State (LACEN/RS) that collaborated with this study.

\section{REFERENCES:}

1. Anderson, W.A.C.; Castle, L. Benzophenone in cartonboard packaging materials and the factors that influence its migration into food. Food Additives and Contaminants 2003, 20, 607-618.

2. Association of Official Analytical Chemists. Pentachlorophenol in gelatin. Gas chromatographic method, first action. In Official Methods of Analysis; AOAC: Washington, 1985; 58-59.

3. Agência Nacional de Vigilância Sanitária (2002). Resolução n. 130, de 10/05/2002 
ANVISA/MS, VISALEGIS. Brasília: Ministry of Health of Brazil. Available at http://www.anvisa.gov.br (accessed Oct 2010).

4. Agência Nacional de Vigilância Sanitária (2006). Resolução n. 164, de 18/08/2006 da ANVISA/MS, VISALEGIS. Brasília: Ministry of Health of Brazil. Available at http://www.anvisa.gov.br.

5. Brazilian Pulp and Paper Association (2008). Brazilian industry performance in 2007 and forecast. Available http://www.bracelpa.org.br.

6. Choi, J.O., Jitsunari, F., Asakawa, F., Park, H.J., Lee, \& D.S. Migration of surrogate contaminants in paper and paperboard into water through polyethylene coating layer. Food Additives and Contaminants, 2002, 19, 1200-1206.

7. Collins, J.J., Bodner, K.M., Wilken, M., Haidar, S., Burns, C.J., Budinsky, R.A., Martin, G.D., Carson, M.L., \& Rowlands, J.C. Serum concentrations of chlorinated dibenzo$p$-dioxins and dibenzofurans among former Michigan trichlorophenol and pentachlorophenol workers. Journal of Exposure Science and Environmental Epidemiology, 2007, 17, 541-548.

8. Demers, P.A., Davies, H.W., Friesen, M.C., Hertzman, C., Ostry, A., Hershler, R., \& Teschke, K. Cancer and occupational exposure to pentachlorophenol and tetrachlorophenol (Canada). Cancer Causes \& Control, 2006,17, 749-758.

9. Di Pasquale, M. Amino acids and proteins for the athlete: the anabolic edge; CRC Press: Boca Raton, USA, 1997.

10. Diserens, J.M. Rapid determination of nineteen chlorophenols in wood paper, cardboard, and fruit juices by gas chromatography mass spectrometry. Journal of AOAC International, 2001,3, 126-134.

11. Kroes, R. Galli, C., Munro, I., Schilter, B., Tran, L.A., Walker, R., \& Würtzen, G. Threshold of toxicological concern for chemical substances present in the diet: A practical tool for assessing the need for toxicity testing. Food and Chemical Toxicology , 2000 , 38, 255-312.

12. Rieder, A ., Dores, E.F.G.C., Higa, N., \& Moraes, M.P.L. Alterações no teor de matéria orgânica de solos e provável efeito no poder de proteção ambiental nas bordas do pantanal diante da poluição por pesticidas. Revista Ecotoxicologia e Meio Ambiente, $2000,10,87-112$.

13. Ozaki, A., Yamaguchi, Y., Fujita, T., Kuroda, K., \& Endo, G. , Chemical analysis and genotoxicological safety assessment of paper and paperboard used for food packaging. Food and Chemical Toxicology, 2004 , 42, 1323-1337.

14. Song, Y.S., Begley, T., Paquette, K., \& Komolpraser, $V$. Effectiveness of polypropylene film as a barrier to migration from recycled paperboard packaging to fatty and high-moisture food. Food Additives and Contaminants, 2003, 20, 875-883.

15. Summerfield, W., \& Cooper, I. Investigation of migration from paper and board into fooddevelopment of methods for rapid testing. Food Additives and Contaminants, 2001, 18, 77-88.

16. Teppner, M. ,Collagen hydrolysate and its relationship to joint health. A science compendium. Eberbach: Gelita Health Initiative, 2004.

17. Triantafyllou, V.I., Karamani, A.G., AkridaDemertzi, K., \& Demertzis, P.G. ,Studies on the usability of recycled PET for food packaging applications. European Food Research and Technology, 2002 , 215, 243248.

18. Triantafyllou, V.I., Akrida-Demertzi, K., \& Demertzis, P.G. ,A study on the migration of organic pollutants from recycled paperboard packaging material to solid food matrices. Food Chemistry,2006, 101, 1759-1768. 


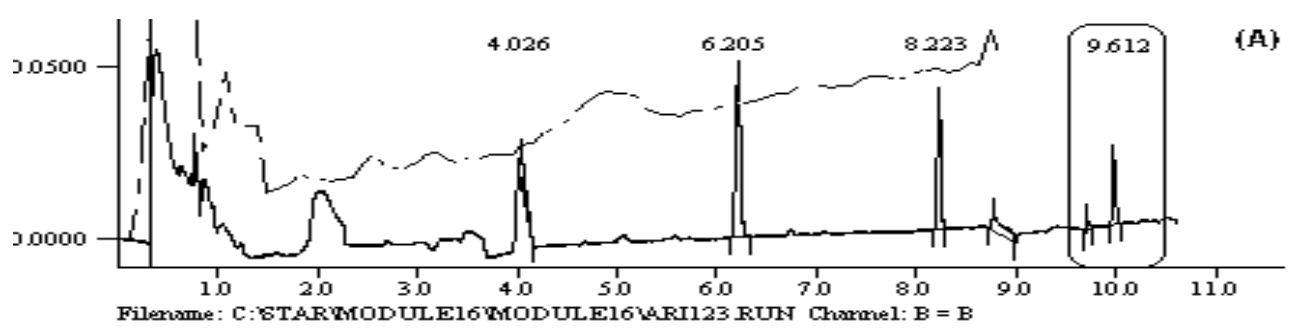

(B)

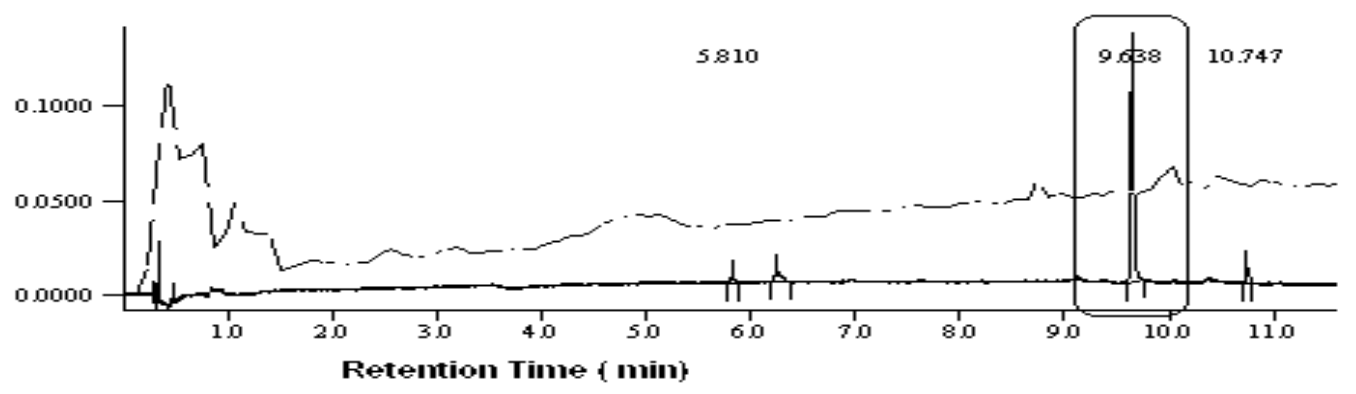

Figure 1. Determination of PCP by GC-ECD. Chromatograms showing (A) presence of PCP in gelatin sample after migration at $60^{\circ} \mathrm{C}$ for $48 \mathrm{~h} ;(B)$ PCP standard solution $\left(0.2 \mathrm{mg} \mathrm{L}^{-1}\right)$.
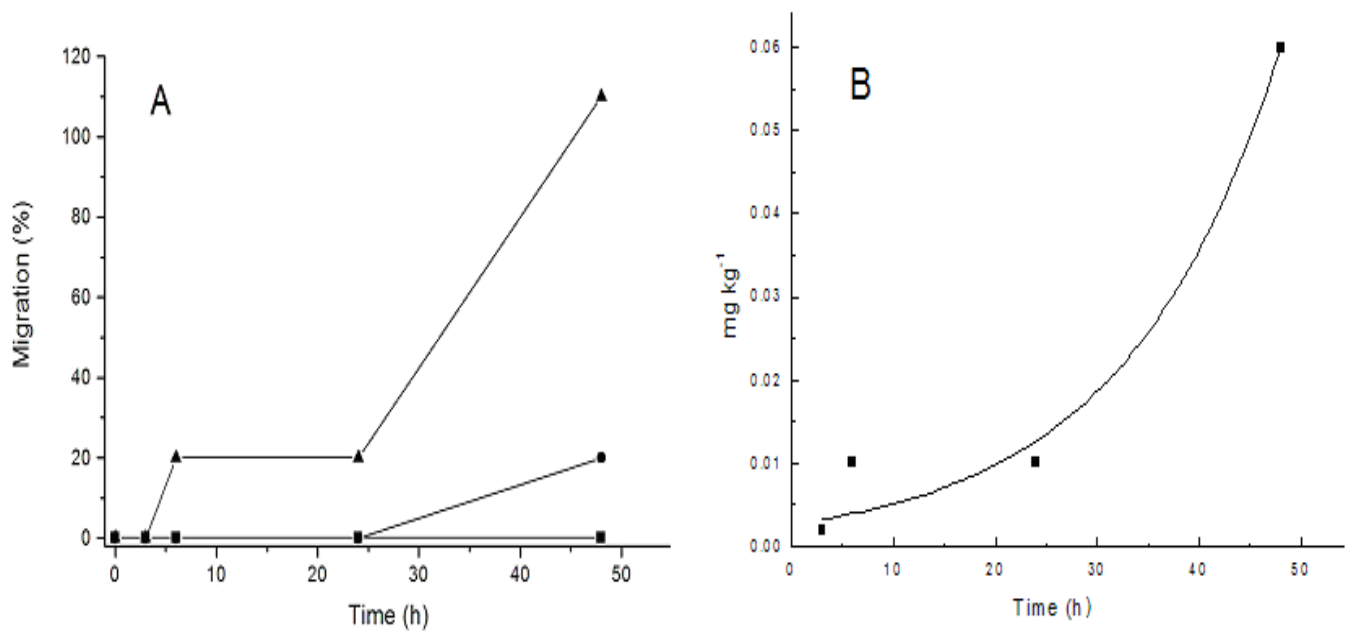

Figure 2. (A) Migration of $P C P$ from secondary cardboard packaging to gelatin matrix after incubation for 3,6 , 24 and $48 \mathrm{~h}$ at $25^{\circ} \mathrm{C}(\mathbf{\bullet}), 40^{\circ} \mathrm{C}(\bullet)$ or $60^{\circ} \mathrm{C}(\mathbf{\Delta})$. (B) $P C P$ migration at $60^{\circ} \mathrm{C}$ fit the exponential model $\left(Y=a e^{b x}\right)$ with $r^{2}=0,979, a=0,0027 \pm 0,0017$ and $b=0,065 \pm 0,013$.

PERIÓDICO TCHÊ QUÍMICA • www.periodico.tchequimica.com • Vol. 13 N. 26.

• ISSN 1806-0374 (impresso) • ISSN 1806-9827 (CD-ROM) • ISSN 2179-0302 (meio eletrônico)

(C) 2016. Porto Alegre, RS. Brasil

The Periódico Tchê Química (ISSN: 1806-0374; 2179-0302) is an open-access journal since 2004. Journal DOI: 10.52571/PTQ. http://www.tchequimica.com. This text was introduced in this file in 2021 for compliance reasons.

() The Author(s)

OPEN ACCESS. This article is licensed under a Creative Commons Attribution 4.0 (CC BY 4.0) International License, which permits use, sharing, adaptation, distribution, and reproduction in any medium or format, as long as you give appropriate credit to the original author(s) and the source, provide a link to the Creative Commons license, and indicate if changes were made. The images or other third-party material in this article are included in the or exceeds the permitted use, you will need to obtain permission directly from the copyright holder. To view a copy of this license, visit http://creativecommons. org/licenses/by/4.0/. 